\title{
ANALYSIS OF GROUNDWATER VULNERABILITY IN COAL MINING AT TANAH LAUT DISTRICT, SOUTH KALIMANTAN
}

\author{
Shenny LINGGASARI ${ }^{\text {(D) }}$, Tedy Agung CAHYADI ${ }^{\text {(D) }}$, Rika ERNAWATI ${ }^{3}$ (D), Ayu \\ UTAMI ${ }^{4}$
}

DOI: 10.21163/GT_2020.151.23

\begin{abstract}
:
A mining plan will affect the water catchment especially on the availability of groundwater. One effort to maintain the quantity and quality of groundwater is analyze the level of groundwater vulnerability. The aim of this research is finding areas that potentially have pollution of groundwater. The analytical method using DRASTIC method. DRASTIC have seven parameters: depth of groundwater (D), recharge (R), aquifer type (A), soil texture (S), topography (T), impact of the vadose zone (I), and hydraulic conductivity (C). DRASTIC divides each parameter into several classes according to rating, and weight based on their effect of groundwater vulnerability. The final results of this study are a map of groundwater vulnerability level using ArcGIS software. The study area has 2,5\% area with very low vulnerability, $75 \%$ low, $20 \%$ moderate and $2,5 \%$ high. Groundwater vulnerability maps can be a guidance for area of mining plan, in order to minimize the negative effects of mining activities.
\end{abstract}

Key-words: Vulnerability, DRASTIC, Groundwater, Coal mining, Kalimantan.

\section{INTRODUCTION}

The term vulnerability began to be used intuitively in the world of hydrogeology in the 1970s in France and was more widely known in the 1980s (Foster, 1987). The model of groundwater vulnerability based the physical condition of the environment has a level of groundwater protection against pollution (Vrba \& Zoporozec, 1994). Groundwater susceptibility is natural (intrinsic) and due to human activities (specific). Intrinsic vulnerability means the aquifer that is susceptible to contamination and attaches to the geological and hydrogeological features. Meanwhile specific susceptibility means the susceptibility of aquifers to a group of pollutants or to only one pollutant (Foster \& Hirata, 1988). The intrinsic vulnerability relying on three elements: His fluid contaminant flow dynamics in the saturated zone; absorption process and fluid contaminant travel time; the residual concentration of the contaminant as it reaches the saturated zone (Maria, 2017).

The quality of groundwater depends on the presence or absence of contaminants entering the groundwater and the physical condition. This causes groundwater to be in the soil layer or subsurface, thus affecting the level of groundwater danger to a pollution. The level of groundwater hazard is a priority by groundwater level itself, as well as the level of contaminants or contaminants that exist. Coal mining activity changes morphology, geology,

\footnotetext{
${ }^{1234}$ UPN Veteran Yogyakarta, Faculty of Mineral Technology, 55583 Yogyakarta, Indonesia shennylinggasari@gmail.com; tedyagungc@upnyk.ac.id.; rika.ernawati@upnyk.ac.id; ayu.utami@upnyk.ac.id.;
} 
hydrogeology, and land use. It can impact on subsurface rock layers, topographic, and aquifers. The water catchment will have an effect on the availability of groundwater both in quality and quantity because the changed of land use (Vias et al., 2005). The decrease of watertable in the mining area is very possible because the elevation of the mine floor is far below the surface of the ground, especially the surface of deep groundwater. Decrease in groundwater potential affects the decrease in groundwater level, groundwater discharge, subsidence (surface or land subsidence), and groundwater quality (Haq et al., 2013). Activities of mining that can bring impact to be pollutions such as, overburden dumping, activities in workshops, the construction of haul road facilities and infrastructure, stockpiling activities, coal processing and disposal of domestic waste from employees. A model for measuring the level of groundwater vulnerability to pollution is important to do with protecting groundwater from pollution caused by mining activities. The aim of this study is determine zone of the groundwater level vulnerability against pollution. The novelty of this research is determining the level of groundwater vulnerability can be applied in the mining area and can be a reference for the government or mining company to manage the groundwater.

\section{STUDY AREA AND DATA}

The study area is located in Tanah Laut, South Kalimantan. It was a tropical climate and located between the latitude of $3^{\circ} 18^{\prime} 25^{\prime \prime} \mathrm{S}$ and longitude $114^{\circ} 33^{\prime} 53^{\prime \prime}$ E. Its 4 hours from Syamsoedin Noor Airport, Banjarbaru. This location is one of coal mining concessions. The area is about $100 \mathrm{~km}^{2}$.

\section{METHODOLOGY}

Many methods to estimate groundwater vulnerability. There are DRASTIC, COP, GOD, SINTACS, EPIK, SI, MEDALUS, KHRERICI, etc (Table 1). Every method has parameters that relate in hydrogeological features. EPIK, GOD, COP, PI, RISKE, REKS, VURAS usually used for karst area. SI can be used in urban, plantation, or agriculture. MEDALUS can be used on an endoreic area or in the highlands (Bouhata \& Kalla, 2014). KHERICI used in reservoir on groundwater (Attoui et al., 2012). Meanwhile DRASTIC and SINTACS have a similarity, but this research only using DRASTIC method because DRASTIC have many parameters than others and can be applied in coal mining area.

DRASTIC is the method most widely known in a variety of regional conditions (Foster $\&$ Hirata, 1988). DRASTIC is an acronym of the parameters within a hydrologic feature, which handle groundwater pollution: depth of groundwater (D), recharge (R), aquifer type (A), soil texture (S), topography (T), impact of vadose zone materials (I), and hydraulic conductivity (C). The DRASTIC model has a result, it's a numerical index from weights and rating assigned the seven parameters. Every parameter has a weight, its about score 1-5 based on the important things, the greater weights means greater pollution probability. Rating of every parameters about 1 to 10 depends on relative effect of vulnerability, if rating 1 means the least pollutant potential and rating 10 means the highest pollutant (Piscopo, 2001). The DRASTIC index is shown in equation below.

DRASTIC Index $(\mathrm{Di})=\mathrm{DrDw}+\mathrm{RrRw}+\mathrm{ArAw}+\mathrm{SrSw}+\mathrm{TrTw}+\mathrm{IrIw}+\mathrm{CrCw}$ 
Where, $\mathrm{w}$ is for weight and $\mathrm{r}$ is for rating.

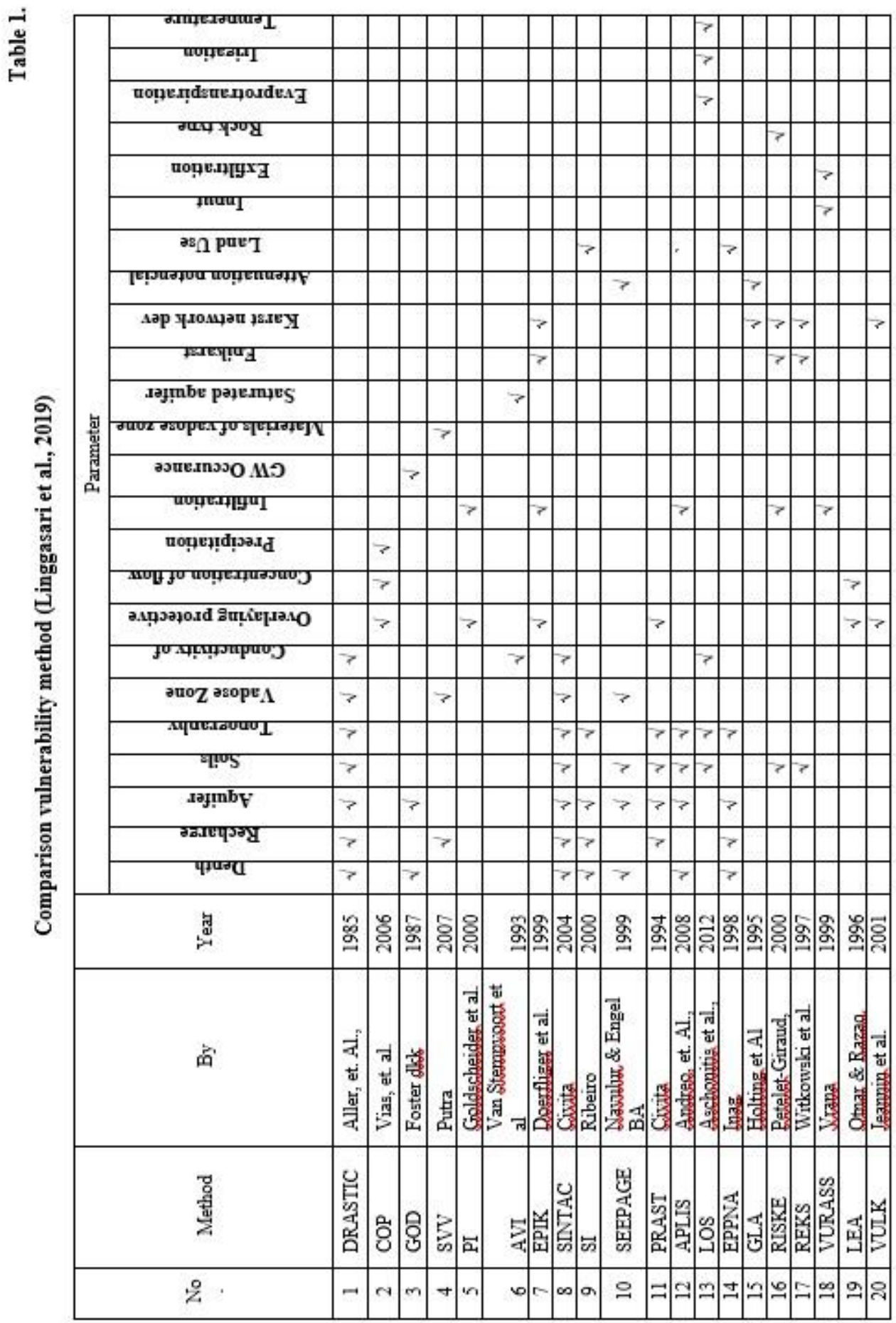




\section{FACTS}

1. Ground water is source used by the community around the mine

2. In the planned increase in the mining area conducted a geohydrology study around the mine.

\section{PROBLEMS}

1. Groundwater conditions require hydrogeological data

2. Mapping groundwater vulnerability with DRASTIC methods will be carried out by overlaying the parameters of ground water level, rainfall, soil media, infiltration, aquifer media, topography, unsaturated zone effects and conductivity hydraulic

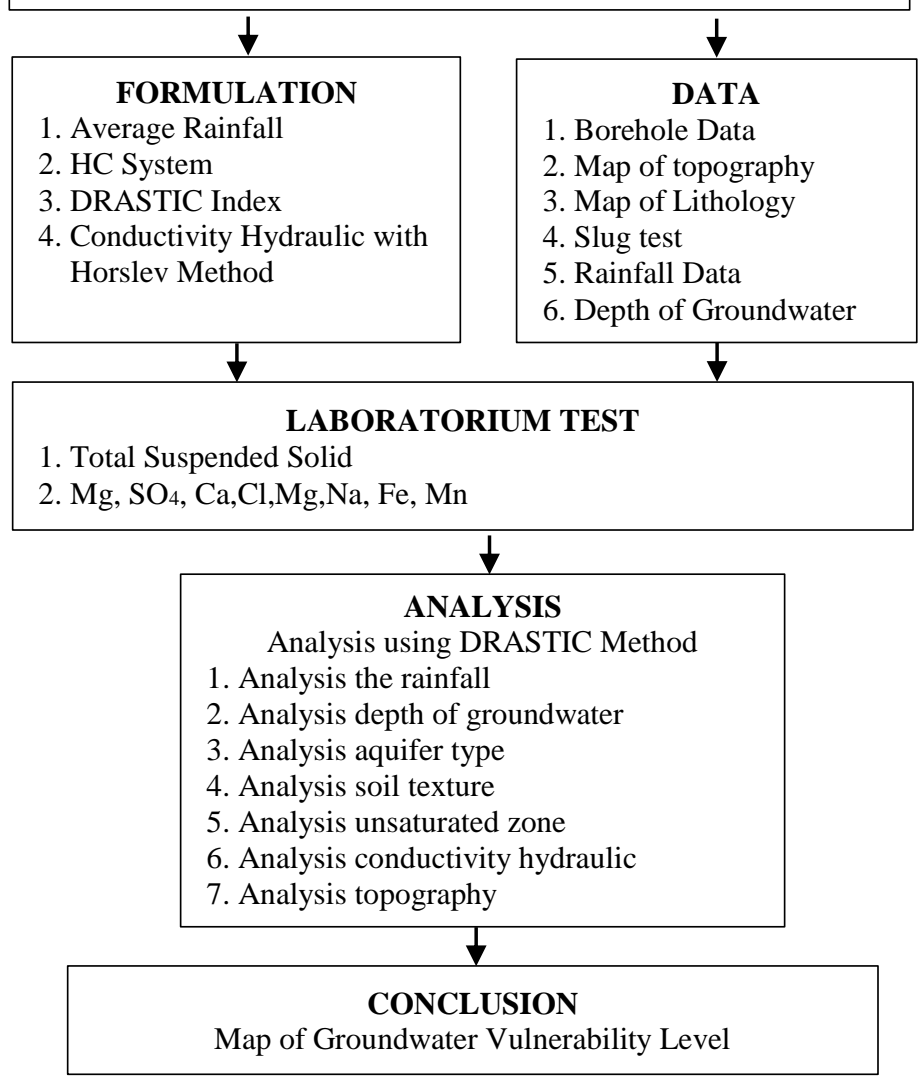

Fig.1. Methodology Flowchart

Increasing DRASTIC index will produce higher groundwater pollution possibility. The classification and rating of DRASTIC can be seen in Table 2 to Table 8, while the assessment of the weight of each parameter is presented in Table $\mathbf{9}$ and class of vulnerability in Table 10. 
Table 2

Classification and Rating of Watertable depth (Aller et al., 1988).

\begin{tabular}{|c|c|c|}
\hline \multicolumn{3}{|c|}{ Depth of GroundWatertable (m) } \\
\hline Class & Range & Rating \\
\hline 1 & $0-1,5$ & 10 \\
\hline 2 & $1,5-4,5$ & 9 \\
\hline 3 & $4,5-9,0$ & 7 \\
\hline 4 & $9,0-15$ & 5 \\
\hline 5 & $15-22,5$ & 3 \\
\hline 6 & $22,5-30$ & 3 \\
\hline 7 & $>30$ & 1 \\
\hline
\end{tabular}

Table 3.

Classification and Rating of Recharge (Aller et al., 1988).

\begin{tabular}{|c|c|c|}
\hline \multicolumn{3}{|c|}{ Recharge (mm/tahun) } \\
\hline Class & Range & Rating \\
\hline 1 & $0-1500$ & 2 \\
\hline 2 & $1500-2000$ & 4 \\
\hline 3 & $2000-2500$ & 6 \\
\hline 4 & $2500-3000$ & 8 \\
\hline 5 & $>3000$ & 10 \\
\hline
\end{tabular}

Table 4.

Classification and Rating of Aquifer Type (Aller et al., 1988).

\begin{tabular}{|c|l|c|}
\hline \multicolumn{2}{|c|}{ Aquifer Type } \\
\hline Class & \multicolumn{1}{|c|}{ Aquifer Type } & Rating \\
\hline 1 & Massive Shale & 2 \\
\hline 2 & Weathered metamorphic/ igneous & 3 \\
\hline 3 & Metamorphic rock & 4 \\
\hline 4 & Sand, shale, limestone & 6 \\
\hline 5 & Massive sand & 6 \\
\hline 6 & Massive limestone & 6 \\
\hline 7 & Sand and gravel & 8 \\
\hline 8 & Basalt & 9 \\
\hline 9 & Limestone, karst & 10 \\
\hline
\end{tabular}

Table 5.

Classification and Rating of Soil Texture (Aller et al., 1988).

\begin{tabular}{|c|l|c|}
\hline \multicolumn{2}{|c|}{ Soil Texture } \\
\hline Class & \multicolumn{1}{|c|}{ Soil } & Rating \\
\hline 1 & Gravel & 10 \\
\hline 2 & Sand & 9 \\
\hline 3 & Shrinking clay & 7 \\
\hline 4 & Sandy loam & 6 \\
\hline 5 & Loam & 5 \\
\hline 6 & Silty loam & 4 \\
\hline 7 & No shrinking clay & 1 \\
\hline
\end{tabular}

Table 6.

Classification and Rating of Topography (Aller et al., 1988).

\begin{tabular}{|c|c|c|}
\hline \multicolumn{3}{|c|}{ Topography(\%) } \\
\hline Class & Range & Rating \\
\hline 1 & $0-2$ & 10 \\
\hline 2 & $2-6$ & 9 \\
\hline 3 & $6-12$ & 5 \\
\hline 4 & $12-18$ & 3 \\
\hline 5 & $>18$ & 1 \\
\hline
\end{tabular}


Table 7.

Classification and Rating of Material In Vadose Zone (Aller et al., 1988).

\begin{tabular}{|c|l|c|}
\hline \multicolumn{2}{|c|}{ Material in vadose zone } \\
\hline Class & \multicolumn{1}{|c|}{ Media } & Rating \\
\hline 1 & Confining layer & 1 \\
\hline 2 & Shale & 3 \\
\hline 3 & Limestone & 6 \\
\hline 4 & Sandstone & 6 \\
\hline 5 & Bedded limestone, Sandstone and shale & 6 \\
\hline 6 & Sand and gravel with silt and loam & 6 \\
\hline 7 & Metamorphic/igneous & 4 \\
\hline 8 & Sand and gravel & 8 \\
\hline 9 & Basalt & 9 \\
\hline 10 & Karst limestone & 10 \\
\hline
\end{tabular}

Table 8.

Classification and Rating of Conductivity Hydraulic (Aller et al., 1988).

\begin{tabular}{|c|c|c|}
\hline \multicolumn{3}{|c|}{ Conductivity Hydraulic (m/year) } \\
\hline Class & Range & Rating \\
\hline 1 & $1-100$ & 1 \\
\hline 2 & $100-300$ & 2 \\
\hline 3 & $300-700$ & 4 \\
\hline 4 & $700-1000$ & 6 \\
\hline 5 & $1000-2000$ & 8 \\
\hline 6 & $>2000$ & 10 \\
\hline
\end{tabular}

Table 9.

Weight of DRASTIC (Aller et al., 1988).

\begin{tabular}{|c|c|c|c|c|c|c|c|}
\hline Parameter & Depth & Recharge & Aquifer & Soil & Topography & In vadose & Conductivity \\
\hline Weight & 5 & 4 & 3 & 2 & 1 & 5 & 3 \\
\hline
\end{tabular}

Table 10.

Criteria of the vulnerability assessment using DRASTIC method.

\begin{tabular}{|l|c|}
\hline \multicolumn{1}{|c|}{ Class of Vulnerability } & Index DRASTIC \\
\hline Very Low & $<79$ \\
\hline Low & $80-119$ \\
\hline Moderate & $120-159$ \\
\hline High & $160-199$ \\
\hline Very High & $>199$ \\
\hline
\end{tabular}

\section{RESULTS AND DISCUSSIONS}

The parameters considered in weighting groundwater vulnerability include depth to ground watertable, recharge, aquifer type, soil texture, topography, impact of vadose zone, hydraulic conductivity. The level of groundwater vulnerability is created by overlapping the seven DRASTIC parameters in the study area.

\section{Depth of Water}

The depth of ground water in mining plan is around 3 to 50 meters. The depth is measured through exploration and geotechnical drill holes. The deeper groundwater surface, the potential for groundwater contamination will be smaller, and vice versa if the groundwater level is increasingly shallow, the potential for groundwater contamination will be even 
greater. This is proven by the deeper groundwater level, the time the contaminant reaches the groundwater level, the longer the potential for contamination will also be smaller.

\section{Recharge}

Recharge calculated by rainfall data. Rainfall in this area is high category, which is around $4000 \mathrm{~mm}$ per year. High rainfall is likely to significantly influence groundwater pollution. High rainfall will affect the high pollutants because the high rainfall makes the infiltration rate higher, and pollutants easier to reach groundwater.

\section{Aquifer Type}

Aquifer type are determined based on rock formations in the study area. The results of interpretation of drill log data show that the aquifer type in the area are sandstone. Grain size of sand stone can affect groundwater vulnerability in mining plans, because sandstone aquifer type makes it possible to keep and pass groundwater in large quantities.

\section{Soil Texture}

Soil has a significant impact on water including dissolved contaminants infiltrated from the surface of the soil into the soil. In general, the finer the grain size, the smaller the potential for dissolved contaminants to enter the soil. Based on the borehole and field observations, the soil texture in the study area is dominated by sandy loam in the western part of the mining plan area. Whereas in the east, dominated by silt and clay. Silt and clays have a big grain size, which can reduce soil permeability and limit the movement of contaminants.

\section{Slope (Topography)}

Topographic maps in the mining plan area are prepared through a digital elevation model (DEM) obtained from USGS. Based on the slope map, the study area has a slope varies between 2 to $74 \%$. Almost all areas is low slope. Area with lower slope causes water to have a chance to seep into the soil, whereas in areas with higher slope water tends to flow immediately.

\section{Impact of Vadose Zone (Unsaturated Zone)}

Material of vadose zone is located above the watertable which is discontinuously saturated or unsaturated. It determined based on the type of the material, including the characteristic or boundary of the soil and rocks below the groundwater level. The material will control the direction and travel time needed to reach groundwater. Based on exploration and geotechnical drilling holes, the unsaturated zone in the mining plan area is dominated by silty clay and a small amount of sand.

\section{Conductivity of Aquifer}

Hydraulic conductivity is defined as the ability of aquifer materials to transmit water, which in turn, controls the rate at which groundwater will flow under a given hydraulic gradient. Aquatic hydraulic conductivity is the ability of aquifers to escape water and affect the speed of the water flow. The greater the value of hydraulic conductivity, the potential for groundwater pollution will also be even greater. Hydraulic conductivity in the mining plan area is $0.17-1.99 \mathrm{~m} /$ day. This value is obtained based on the slug test that has been done.

Based on identification of the seven parameters above, the results of the field shown on the Table 11. 
The result of DRASTIC Index.

Table 11.

\begin{tabular}{|c|c|c|c|c|c|c|c|c|c|c|c|c|}
\hline \multirow{2}{*}{ Level of Vulnerability } & \multicolumn{3}{|c|}{ Very Low } & \multicolumn{3}{|c|}{ Low } & \multicolumn{3}{|c|}{ Moderate } & \multicolumn{3}{|c|}{ High } \\
\hline & $R$ & $\mathbf{W}$ & Score & $R$ & $\mathbf{W}$ & Score & $R$ & $\mathbf{W}$ & Score & $R$ & $\mathbf{W}$ & Score \\
\hline Depth of Watertable & 1 & 5 & 5 & $1-7$ & 5 & $5-35$ & $3-9$ & 5 & $15-45$ & 10 & 5 & 50 \\
\hline Recharge & 10 & 4 & 40 & 10 & 4 & 40 & 10 & 4 & 40 & 10 & 4 & 40 \\
\hline Aquifer Type & 6 & 3 & 18 & 6 & 3 & 18 & 6 & 3 & 18 & 6 & 3 & 18 \\
\hline Soil Texture & $4-6$ & 2 & $8-12$ & $4-6$ & 2 & $8-12$ & $4-6$ & 2 & $8-12$ & 6 & 2 & 12 \\
\hline Topography & 1 & 1 & 1 & $1-9$ & 1 & $1-9$ & $1-10$ & 1 & $1-10$ & 10 & 1 & 10 \\
\hline $\begin{array}{l}\text { Impact of vadose } \\
\text { zone }\end{array}$ & 1 & 5 & 5 & $1-6$ & 5 & $5-30$ & $1-6$ & 5 & $5-30$ & 6 & 5 & 30 \\
\hline $\begin{array}{l}\text { Conductivity } \\
\text { Hydraulic }\end{array}$ & 1 & 3 & 3 & $1-2$ & 3 & $3-6$ & 1 & 3 & 3 & 2 & 3 & 6 \\
\hline
\end{tabular}

\section{Groundwater Vulnerability Map}

Every parameters of the DRASTIC model have been determined as a part with ArcGIS 10 software. The Geostatistical Analyst with Inverse Distance Weighted (IDW) interpolation in ArcGIS was used to create the raster map and graph and interpolate the points. The map of groundwater vulnerability interpreted by score of DRASTIC indices. DRASTIC index of this study divided into 4 classes (Fig.2). A greater index DRASTIC indicates a higher level of vulnerability, while a smaller value indicates a lower level of vulnerability. After DRASTIC values in each drill hole are obtained, then interpolated using the Inverse Distance Weight method to obtain delineation between points, so that the zone in the study area is known. The results is the study area has a very low level of vulnerability, low, moderate, and high. Based on the DRASTIC classification, the distribution of groundwater vulnerability levels dominated in low range.

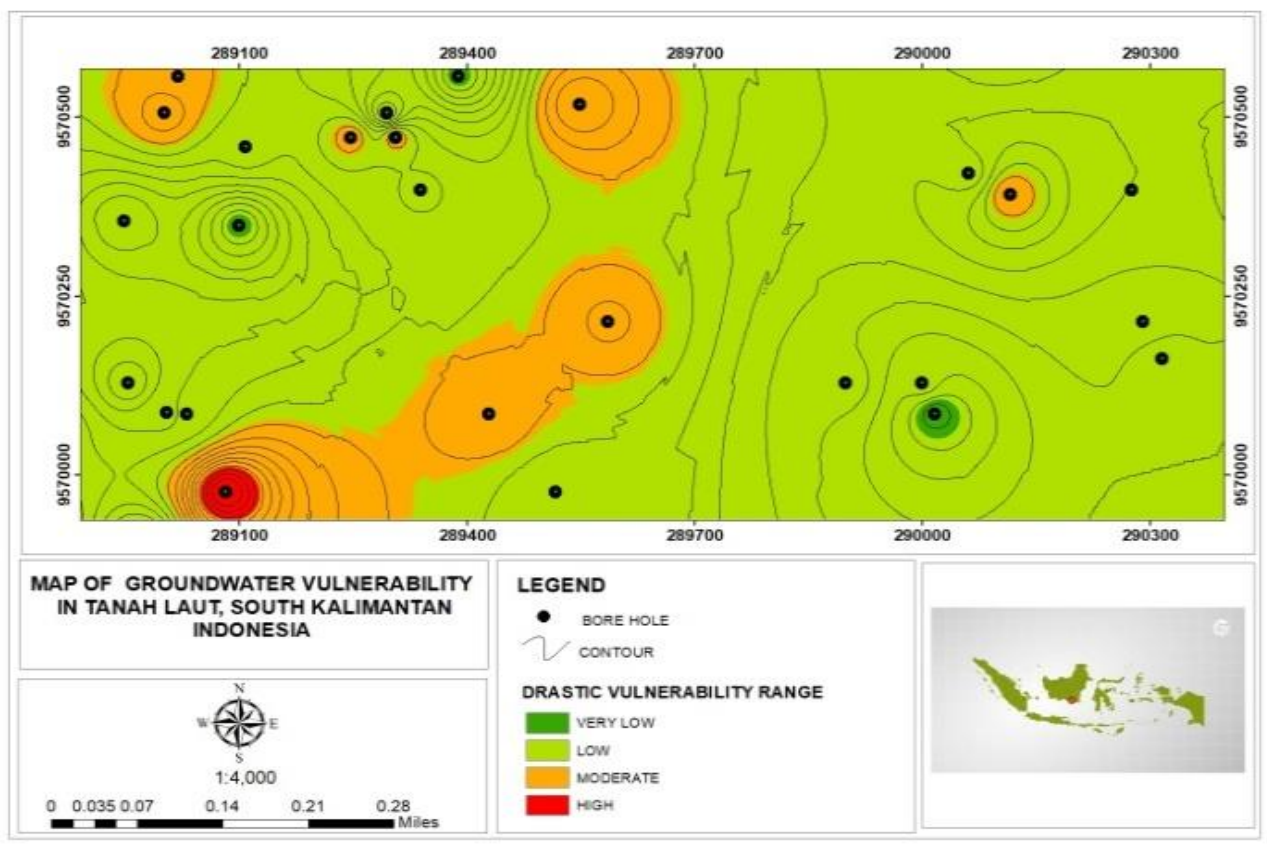

Fig. 2. Map of Groundwater Vulnerability. 


\section{Verification}

Groundwater quality measurements were carried out both in the field and in the laboratory at seven drill holes (Fig. 3) to determine the physical and chemical character of groundwater. This measurement used as a verification of groundwater vulnerability analysis. The measured have eight parameters, Iron $(\mathrm{Fe})$, Manganese $(\mathrm{Mn})$, Chloride $(\mathrm{Cl})$, Sulfate $\left(\mathrm{SO}_{4}\right)$, Calcium (Ca), Magnesium (Mg), Total Suspended Solid (TSS) and $\mathrm{pH}$.

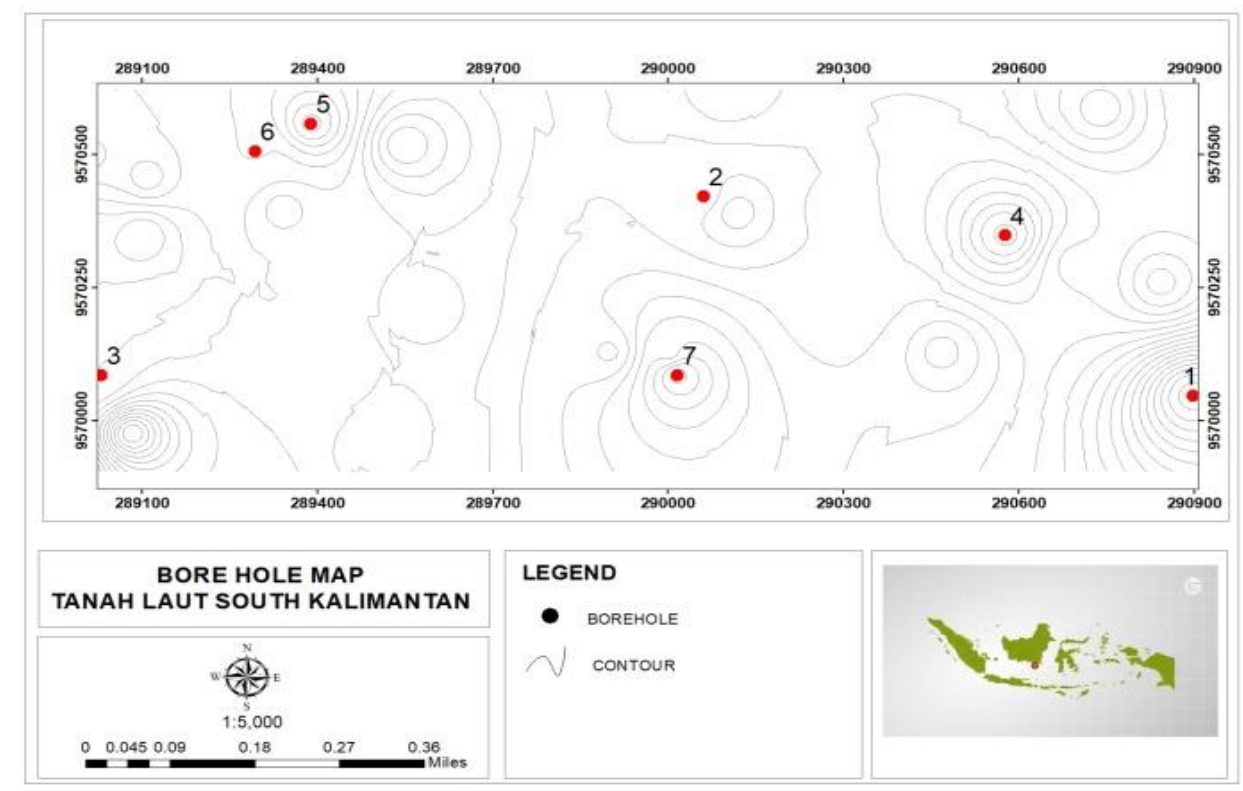

Fig. 3. Map of Borehole.

Based on the correlation coefficient of eight parameters above with DRASTIC index, concluded that the Fe parameter has the greatest correlation coefficient value (81\%) than the other parameters. This is evidenced in the drill holes that have the highest DRASTIC index also contains the highest Fe metal.

\section{CONCLUSIONS}

The zoning results of groundwater vulnerability are divided into four categories: very low, low, medium and high. The level of groundwater vulnerability is very low located in the southeast around $2.5 \%$ of the total research area. Low groundwater vulnerability dominates the study area with $75 \%$ of the total area. The moderate level of vulnerability covers $10 \%$. While the high level of vulnerability is located in the southern part of the study area, which is $2.5 \%$. This area needs groundwater monitoring periodically covers the quality and quantity of groundwater and have a priority for groundwater management related to the location of planned facilities and infrastructure, so as to minimize the impact of coal mining on groundwater in the study area. The area with very low until low vulnerability can be used for 
workshop, fuel station, settling pond. The area with moderate until high vulnerability is for parking vehicles and heavy unit. If a high vulnerability area will be mined, it must be carried out in an area that is less than the ground water level or make sure to prepare growing process.

\section{ACKNOWLEDGE}

The author acknowledges for Mining Engineering UPN "Veteran" Yogyakarta and LPPM UPN "Veteran" Yogyakarta that provided the opportunity to write papers.

\section{R E F E R E N C E S}

Aller, L., Bennet, T., Lehr, J. H., Petty, R. J. \& Hackett, G. (1987) DRASTIC: A Standardized System for Evaluating Groundwater Pollution Potential Using Hydrogeologic Settings, EPA/600/287/035, US Environmental Protection Agency, USA.

Attoui, B., Khaerci, N. \& Bousnoubra, H. (2012) State of Vulnerability to Pollution of the big reservoir of Groundwater in the Region of Annaba-Bouteldja (Ne Algeria). Geographia Technica, 7 (2), 113.

Bouhata, R. \& Kalla, M. (2014) Mapping of Environmental Vulnerability of Desertification byAdaptation of the Medolus Method in The Endoric Area of Gadaine. Geographia Technica, 9 (2), 1-8.

Foster, SSD. (1987) Fundamental concepts in aquifer vulnerability, pollution risk and protection strategy. In: Van Duijvenbooden W, Van Waegeningh HG (eds) TNO committee on hydrological research. Vulnerability of soil and groundwater to pollutant The Netherlands.

Foster, S. \& Hirata, R. (1988) Groundwater Pollution Risk Assessment; A Methodology Using Available Data, PAN American Center for Sanitary Engineering and Environmental Sciences (CEPIS), Lima, Peru.

Haq, S. R., Dwinagara, B., Triana, K. \& Cahyadi, T. A. (2013) Analisis Tingkat Kerentanan Air Tanah Pada Rencana Pertambangan Batubara di Barito Timur, Kalimantan Tengah. Prosiding TPT XXII PERHAPI.

Linggasari S., Cahyadi, T.A. \& Ernawati, R. (2019) Overview Metode Perhitungan Kerentanan Air Tanah Terhadap Rencana Penambangan. Proceeding RETII-14.

Maria, R. (2017) Comparative studies of groundwater vulnerability assessment. Global Colloquium on GeoSciences and Engineering, Bandung.

Piscopo, G. (2001) Groundwater Vulnerability Map Explanatory Notes, NSW Department of Land and Water Conservation.

Vias, J.M., Andreo, B., Peries, M. J. \& Carrasco, F. (2005) A Comparative Study of Four Schemes for Groundwater Vulnerability Mapping in A Diffuse Flow Carbonate Aquifer Under Mediterranean Climatic Conditions. Enviro Geology, 47 (1), 586-595.

Vrba, J. \& Zoporozec, A. (1994) Guidebook on Mapping Groundwater Vulnerability, International Association of Hydrogeologist, Hannover. 